\title{
The Impact of Talent Management on Resident Doctor Performance at Jordanian Ministry of Health Educational Hospitals
}

\author{
Dirgham Ameen Atoom ${ }^{1}$ \\ ${ }^{1}$ University of Southern Queensland, Australia \\ Correspondence: Dirgham Ameen Atoom, University of Southern Queensland, Australia.
}

Received: May 6, 2018

doi:10.5430/ijba.v9n4p33
Accepted: June 21, 2018

Online Published: June 27, 2018

\begin{abstract}
This study aims to identify the impact of talent management on medical physician performance at the Jordan ministry of health educational hospitals. However, the population of study was the resident physicians at the three educational hospitals (Prince HAMZA, Princess BASMA and AL-Karak), and the number of population was (478) male and female doctors, and the study sample consisted of (77) male and female resident physicians at the educational hospitals, forming (16\%) of the study population. On the other hand, the two researchers relied on the questionnaire in order to collect data on the study sample, and they relied on the descriptive approach and single and multiple regression to analyze the data. The results of study show the following: that the level of talent management application at the three educational hospitals came with moderate level, and the arithmetic mean for the estimates of sample individuals on resident doctors areas was moderate at large, also, there is a significant statistically impact at $(\alpha \leq 0.05)$ for the management of talents in its dimensions on the resident physician performance, but with moderate level, also there is impact of talent management on all physician performance dimensions (morning report presentation, doing morning round, examining and admitting the patients at night and evening shift and coordinating with other departments in hospital for diagnostic procedures).
\end{abstract}

So, the study recommended that education hospitals should develop systems and programs to attract, select, develop, evaluate the talent and make available all tools necessary to retain talent physician and keep abreast with modern management thought in talent management practice at the educational Jordanian hospitals.

Keywords: talent management, resident doctor performance, educational hospital

\section{Introduction}

With the spread of globalization and the potential for extensive horizons in various commercial and educational areas, and people openness on one another, all of that have led to a sharp competition among major global companies in seizing investment opportunities, broad attraction for human resources from different countries and cultures, however, many researchers pointed to poor attention in the area of talent management in the whole world where Michaels et al., (2001) indicated that 19\% of the organizations attract gifted employees, and, the rate of effective development stands at 3\% for talents, and $26 \%$ for senior management of such organizations, management of talents place the talent at the first three priorities, and this uncovers poor attention to talent management on the part of global organizations.

Talent means whatever distinguishes man from another, whereas the management of talents is the process of attracting and appointing, exploring, training and stimulating the talents, whether from inside or outside the organization. Where, management of talents seeks to cover the organization needs of current and futures qualified cadres, so, the organization would appoint the right person at the right place and time.

However, general health sector in Jordan is deemed the main vein to offering health services to community. The quality of services offered via this sector reflects the well-being and development of the community. However, community will not attain welfare state without having medical and health personnel with high-quality of talent, expertise and knowledge. And, thereby, health sector in Jordan is considered a service sector, and the quality of services offered rely heavily on what such medical employees have of distinct qualifications, and skills driving them to provide better service. In this respect, resident doctors are considered an important part of the MOH employees, and resident doctors have many roles and functions, including, preparation for the daily work programs, performance 
of morning rounds to patients with specialist doctors, provision of daily morning reports to specialist doctors on the patients, and following-up the diagnostic procedures and medical orders and carrying out patients examination and admission during night shifts and providing them with consultations.

Consequently, the aim of study is to measure the impact of talent management on resident doctors performance at the Jordan $\mathrm{MOH}$ educational hospitals.

\section{Study Problem and Components}

The importance of talent management and poor attention to it was revealed through the survey conducted by the two researchers of previous studies, including, AL-JARRAH \& ABU DAWLA (2015), and KEVEN (2012), especially, that it represents one of this ages titles. Thus, both researchers had conducted many documented interviews with resident doctors at the $\mathrm{MOH}$, where the questions centered on the concept of talent management and the extent of its implementation at the educational hospitals and its impact on performance; many resident doctors voiced about poor implementation of talent management and what might result of great difficulty in their performance at the Jordan MOH educational hospitals, and thereby, there appeared a problem worth studying which is poor interest in talent management, and its impact on the resident doctors performance at the Jordan MOH educational hospitals. Therefore, the purpose of study is to determine the impact of talents management on resident doctors at the Jordan MOH educational hospitals.

\subsection{Concept of Talent and Management of Talents}

Talent is defined as those individuals who can create great a difference in organization performance, either by way of their contributions directly to performance or through achieving higher levels of performance and on the long run (Armstrong, 2009). As for SALEH \& AL-SUDANI (2010), they defined talent as that intellectual advanced power created by complicated features qualifies its holder to complete tasks characterized by challenge, innovation and adds value to the organization, on the other hand, the concepts of talents management is considered among the critical and confusing at the present time for what the impact the talents management has on organizations, where Susan (2014) defined it as the organization obligation to appoint and sustain and develop talented employees existing in the labor market. Furthermore, SCHULAER (1990) defined talents management as making sure that the right people are in the right jobs and at the right time. Whereas, WAHEED et al., (2001) see that talent management is a system that oversees the identification of the most important and sensitive jobs in the organization which contribute to achieving the competitive feature through supplying it with proper workforce to carry out work with higher efficiency and competence.

\section{Attraction of Talent}

The process of attracting talent covers all policies and practices through which gifted individuals are attracted (TARIQUE \& Schuler, 2012). And, this would allow the organization attracting talents to place the right talent at the right time and place and at all levels (GUTHRIDGE et al., 2008).

\section{Selection of Talent}

The process of talent selection is not just to select the best person from among the candidates but looking for the best candidate, yet, most organizations are still using the same strategies in the selection and appointment, so, organizations must change the selection principles and strategies to cover all administrative levels, as old selection methods were restricted to human resources administration, and to deal with all applicants on the same footing, yet, in modern methods, all managers are responsible for the selection and nomination of the gifted persons so that each business unit must have a special strategy for job selection (MICHEALS et al., 2001)>

\section{Talents Development}

The process of talents development covers four large areas as mentioned by CARBUN \& CARAN 2012, they are:

Specifying the identity (to whom development should go? Who's the employees in need to be developed?)

Design (what abilities that must be developed and the time needed for that?)

Appraisal (what are the analytical tools used in measuring the efficacy?)

Organizational support (what support that can be presented by senior management?).

\section{Sustainability of Talents}

Sustainability of talents aims to encourage employees to remain with the organization for the longest possible time; as quitting of employee would harm the organization interests due to the cost of attracting and replacing a gifted 
employee in lieu of another (Echols, 2007). On the other hand, VAIMANEN (2008) defined two categories of businesses, practiced by organizations in order to retain gifted employees, they are: internal and external incentives, internal incentives get back to immaterial prizes and rewards which satisfy the physiological needs of gifted employees.

\section{Job Performance}

The success of organization, whatever its business nature was, depends on individual and workers, the extent of mastering work and skills, yet, job performance is considered an important element as being one of the most important resources available in private and governmental organizations. So, the organization survival and continuity and efficiency in providing its products and the high level of its productivity depend on its human resources performance level which would help in creating an added value to all resources of the organization (AQILI, 2005, p.5), also, Arnold \& Feldman (1983), see that performance is the amount of positive impact of workers toward their jobs in the organization at which they work, hence, many intellects and scholars and researchers tend to discriminate between the performance and achievement of goals and behavior where they see that performance is the interaction between the achievement of goals and behavior, in other words, it expresses the aggregate works and results together. And, they see also, that achieving the goals is what remains of results when individuals stop working. And, see that behavior is what the individuals do in the organizations they work with (BARTRAM \& Casmir, P.4, 2007).

According to David et al., (2013), the process of appraisal consists of six steps:

1. Formation and creation of performance standards with employees.

2. Communication with employees about their expectations.

3. Measurement of actual performance.

4. Comparison of actual performance with the standards developed.

5. Discussion of appraisal with employees.

6. Taking the corrective measures, if required.

Moreover, David et al., (2013) added that there are three appraisal methods:

1. Absolute standards: in which employee performance is measured by establishing fixed standards irrespective of other employees in the action group.

2. Relative standards: employee performance is appraised by comparing it with other employees' performance in the same action group.

3. Deliverables (goals management): performance is appraised based on the extent to which the goals, already developed, are achieved.

\section{Previous Studies}

First: Studies in Arabic

Both researchers could exert the required effort to look for studies relevant to the subject matter through which their study can be enriched, for example, the study of AL-KASASBEH (2016) that aimed to measure the impact of talent management and organizational education on Jordan ZEIN Company sustainability. The study concluded that the conception of subjects on the talent management elements in ZEIN company is high and an impact is there for the talent management and organizational education on the sustainability of Jordan ZEIN Company.

Yet, the study of JARRAH \& ABU DOLEH (2015), aimed to learn about the impact of applying talent management strategies on augmenting the organizational affiliation. The study concluded that the level of applying talent management strategies, at the official Jordan universities was moderate, yet the level of organizational affiliation was moderate in general, also the study showed the presence of a significant and positive direct correlation for the level of talent management strategies applications at the organizational affiliation level. Furthermore, the study of AL-SAEED (2013), sought to explain the impact of talent management, on the merger of two factors, the functional and organizational, and to determine whether equilibrium variable between work and family is mediated by this correlation or not. However, the results signified that talent management impacts each of the functional and organizational merger of the doctors working at hospitals, also, the study illustrated that the equilibrium variable between work and family interposes this correlation between talent management and the merger of the two functional and organizational factors. Further, the study suggested to attend to talent management for the positive 
impact it has on increased merger between the two factors and, there should be a balance between work and family among employees.

Second: Studies in English

After looking through the studies in English relevant to the study subject matter including the study of PIANSOONGNERN \& ANURIT (2015) which tackled the perspective of Human Resources Management employees in talent management and the factors affecting talent effective management in Thailand. The study concluded that talent management is still a critical issue for the private and government organizations in Thailand, yet, in the study of KAUR (2013) that aimed to learn about the impact of talent management programs on employees performance and their retention at the Supermarkets in India. The study concluded that most employees are content with the talent management programs at the Supermarkets (Big Bazaar) and has a positive impact on the performance and retention of employees, as well as, the study of LAKE (2013) sought to appraise and verify the interns performance in Australia. The study concluded that the least element in performance was in the emergencies and diagnostics procedures management, and the highest one in the communication skills.

\section{Study Population and Sample}

Study population consisted of all doctors resident at the three educational hospitals (Prince HAMZA, Princess BASMA and Al-KARAK), numbering (477) male and female doctors, and the two researchers selected the sample by random sampling method from the population, and thus the sample consisted of (77) male and female doctors resident at the said educational hospitals, forming thereby (16\%) of the population, as set out in tablen 1 . The study used the descriptive analytical approach in analyzing the data which was recorded and displayed by way of tables after having been processed statistically using the SPSS (statistical package for social sciences).

Table 1. Distribution of the study subjects of sample and population by the three educational hospitals (Prince HAMZA, Princess BASMA and AL-KARAK)

\begin{tabular}{lccc}
\hline \multicolumn{1}{c}{ Educational hospitals } & Total number & Sample number & Percentage \\
\hline Prince HAMZA educational hospital & 194 & 34 & $17 \%$ \\
Princess BSAMA educational hospital & 177 & 28 & $15 \%$ \\
AL-KARAK educational hospital & 106 & 15 & $14 \%$ \\
\hline
\end{tabular}

\section{Study Model}

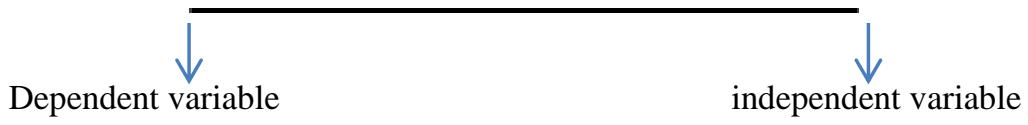

Resident doctors' performance

Talents management

$\begin{array}{ll}\text { - } & \text { Provide morning reports } \\ \text { - } & \text { Morning tours to patients } \\ \text { - } & \text { Follow up diagnostic procedures } \\ & \begin{array}{l}\text { Examine and admit patients } \\ \text { during evening and night shifts }\end{array}\end{array}$

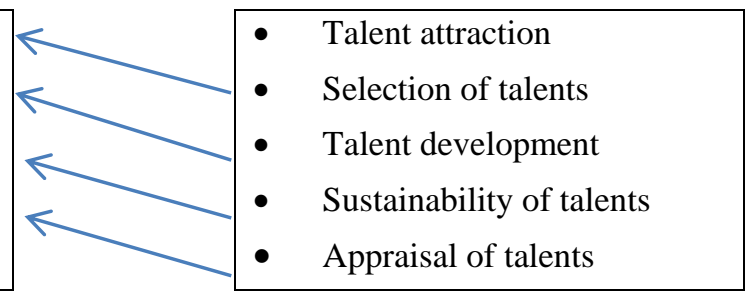

Figure 1

Source: prepared by both researchers based on the following resources: AL-JARRAH \& ABU DOLA (2015), OLADOPA (2014), HAMIDI et al., (2014), GOLCHIN (2014), CHOUDHARY (2014), Jordan Ministry of Health (job description for resident doctors)

\section{Study Hypothesis}

\subsection{Main Hypothesis}

There is no a statistically significant impact at the significance level of $(0,05=\alpha)$ for the talents management in its dimensions (attraction, selection, development, sustainability and appraisal) on the resident doctors performance in 
its dimensions (provision of morning reports, carrying out morning rounds, following up diagnostic procedures, examination and admission of patients) at the educational hospitals of the Jordanian Ministry of Health.

\subsection{This Hypothesis Subdivides Into the Following Assumptions}

There is no a statistically significant impact at the significance level of $(0,05=\alpha)$ for talents management in its dimensions (attraction, selection, development, sustainability and appraisal) on providing morning reports by the resident doctors on the patients at educational hospitals of the Jordan MOH.

There is no a statistically significant impact at the significance level of $(0,05=\alpha)$ for talents management in its dimensions (attraction, selection, development, sustainability and appraisal) on carrying out morning rounds by the resident doctors to the patients at educational hospitals of the Jordanian $\mathrm{MOH}$.

There is no a statistically significant impact at the significance level of $(0,05=\alpha)$ for talents management in its dimensions (attraction, selection, development, sustainability and appraisal) on carrying out diagnostic procedures by the resident doctors on the patients at educational hospitals of the Jordanian MOH.

There is no a statistically significant impact at the significance level of $(0,05=\alpha)$ for talents management in its dimensions (attraction, selection, development, sustainability and appraisal) on carrying out the examination and admission of patients by the resident doctors at educational hospitals of the Jordanian $\mathrm{MOH}$.

\section{Study Tool}

In order to attain the study goals and to answer and test its questions and assumption, a questionnaire was developed using the previous study literatures, AL-KASASBEH, 2015; AL-JARRAH \& ABU DOLEH, 2015; AL-SAEED, 2013 studies. A measure was developed to identify the impact of talents management on resident doctors performance at the Jordanian MOH educational hospitals, where the questionnaire consisted of (55) clauses divided over three sections, the first section addressed an introduction about the research title and requested of the sample individuals to answer the questionnaire clauses. While, the second section addressed the areas of talents management and included (33) clauses divided over five areas: appraisal of talents, sustainability of talents, development of talents, selection of talents and attraction of talents. Whereas, the third section addressed the areas of resident doctors performance and included (22) clauses divided over four areas: (provisions of morning reports and academic duties, carrying out morning rounds to patients, follow-up of diagnostic procedures and medical orders for patients, examination and admission of patients during night and evening shifts), according to LIKERT Penta-Scale and as follows: (agreed with very high level, agreed with high level, agreed with moderate level, disagreed with low level, disagreed with very low level).

\section{Validity and Reliability of Study Tool}

To check the validity of study tool, both researchers have proposed it to a group of (13) competent and experienced referees from the faculty members at the administration sections of colleges at the Jordan universities, and as for the tool reliability, Cronbach's Alpha Coefficient Method was used to identify the internal consistency of clauses, so, reliability values of the areas ranged between (0.77-0.93), and (0.94) for the whole variables, which are acceptable values to conduct such a study.

\section{Study Findings}

Both researchers have analyzed the sample views to understand the special terms of talents management impact on resident doctors at the educational hospitals of the Jordanian $\mathrm{MOH}$, and thereby, arithmetic means and standard deviations were calculated for each variable of the study, and as follows:

First: independent variable (talents management)

Table 2. Arithmetic means for the estimates of sample individuals on talents management variables arranged downward by the arithmetic means $(\mathrm{n}=77)$

\begin{tabular}{lcc}
\hline \multicolumn{1}{c}{ Talents management } & Arithmetic mean * & Level \\
\hline Selection of talent variable & 2,50 & Moderate \\
Talent appraisal variable & 2.49 & Moderate \\
Talent development variable & 2.44 & Moderate \\
Talent attraction variable & 2.40 & Moderate \\
Sustainability of talent variable & 2.27 & Low \\
\hline
\end{tabular}


Table 2 shows that the "variable of talents selection" has occupied the first position with an arithmetic mean of $(2,50)$ and standard deviation of $(0,76)$ with moderate mean, and the "variable of talents appraisal" came next with an arithmetic mean of $(2,49)$ and standard deviation of $(0,74)$ with moderate level, and the "variable of talents sustainability" came in the last position with an arithmetic of $(2,27)$ and standard deviation of $(0,75)$ with low level, however, the arithmetic mean for sample individuals estimates on the talents management variable as a whole amounted to $(2,42)$ with standard deviation of $(0,6943)$, and corresponds to moderate level. It's noticed from that the ambiguity of talents management concept relative to those in charge of educational hospitals of the Jordanian $\mathrm{MOH}$ in terms of principles, practices and dimensions, yet, as for the variable of talents selection coming in the first place this may be ascribed to that the educational hospitals of the $\mathrm{MOH}$ do practice some requirements of the gifted doctors selection, and for having the last position by the talents sustainability variable this may be attributed to that educational hospitals are not recognizing the importance of talents sustainability and they have no methods, instruments and resources needed to sustain resident doctors such as material and immaterial incentives to be an incubating environment for the resident doctors.

Third: Dependent variable (performance of resident doctors)

Table 3. Arithmetic means of the sample individuals estimates on the variable of resident doctors arranged downwardly according to arithmetic means

\begin{tabular}{lcc}
\hline \multicolumn{1}{c}{ Areas } & Arithmetic mean * & Performance Level \\
\hline $\begin{array}{l}\text { Variable of examining and admitting patients } \\
\text { during evening and night shifts }\end{array}$ & 3.83 & High \\
$\begin{array}{l}\text { Variable of following-up diagnostic } \\
\text { procedures and medical orders for the patients }\end{array}$ & 3.69 & High \\
$\begin{array}{l}\text { Variable of conducting morning rounds to } \\
\text { patients }\end{array}$ & 3.43 & Moderate \\
$\begin{array}{l}\text { Variable of providing morning reports and } \\
\text { academic duties }\end{array}$ & 3.05 & Moderate \\
\hline
\end{tabular}

Table 3 shows that the "variable of examining and admitting patients during night and evening shifts" is ranked the first with an arithmetic mean of $(3,83)$ and a standard deviation of $(0,48)$ with high level, and the variable of "following up diagnostic procedures and medical orders for patients" came next with an arithmetic mean of $(3,69)$ and a standard deviation of $(0,72)$ with high level and, the "variable of providing morning reports and academic duties" came in the last position with an arithmetic mean of $(3,05)$ and a standard deviation of $(0,74)$ with moderate level; on the other hand, the arithmetic mean of sample individuals estimates on the variables of resident doctors performance as a whole came to $(3,54)$ which corresponds to moderate level. However, moderate level of resident doctors performance at the educational hospitals is ascribed to the pressure and great number of patients who visit the educational hospitals, and the lacking of an incentive system versus the great effort and work carried out by resident doctors at the educational hospitals; yet, as for having the first rank by the variable of examination and admission of patients during evening shifts and with high level, it can be said that is ascribed to that resident doctors are the only ones in charge of examining and admitting the patients during evening and night shifts where specialist doctors are not then present, and thus all medical procedures are their responsibility, and as for occupying the last rank by the variable of providing morning reports and academic duties and with moderate level that can be explained for the lacking of attention by all specialist doctors in charge of these morning reports provided by resident doctors or; otherwise resident doctors are busy with other medical works, and such morning reports are not linked with the level of appraising resident doctors' performance or with material and immaterial incentives offered to them.

\section{Testing Study Hypothesis}

To verify the main hypothesis "There is no a statistically significant impact at the significance level of $(0,05=\alpha)$ for the talents management in its dimensions (attraction, selection, development, sustainability and appraisal) on the resident doctors performance in its dimensions (provision of morning reports, carrying out morning rounds, following up diagnostic procedures, examination and admission of patients) at the educational hospitals of the Jordanian Ministry of Health". 
And to prove this assumption, Person's correlation coefficients were calculated between the estimates of sample individuals on talents management variables and respective estimates on the resident doctors performance as a whole, where results were as illustrated in table (4).

Table 4. Person's correlation coefficients between the estimates of sample individuals on the variables of talents management and respective estimates on resident doctors' performance as a whole

\begin{tabular}{|c|c|c|}
\hline \multirow[b]{2}{*}{ Variables } & \multicolumn{2}{|c|}{ Resident doctors performance as a whole } \\
\hline & $\begin{array}{l}\text { Correlation } \\
\text { coefficient }\end{array}$ & $\begin{array}{l}\text { Statistical } \\
\text { significance }\end{array}$ \\
\hline Variable of talents attraction & 0,31 & $0.008 *$ \\
\hline Variable of talents selection & 0.35 & $0.002 *$ \\
\hline Variable of talents development & 0.39 & $0.000 *$ \\
\hline Variable of talents sustainability & 0.39 & $0.000 *$ \\
\hline Variable of talents appraisal & 0.45 & $0.000 *$ \\
\hline
\end{tabular}

Table 4 shows that there is a statistically significant impact at level $(\alpha \leq 0.05)$ between the estimates of sample individuals on talents management variables and respective estimates on the resident doctors performance as a whole.

And, to know the size of talents management impact and estimates on the resident doctors performance at large, multiple linear regression analysis was conducted, where the results were as set out in the table 5 .

Table 5. Results of implementing multiple regression analysis to study talents management variables and estimates on resident doctors performance at large $(n=77)$

\begin{tabular}{lccc}
\hline $\begin{array}{c}\text { Independent } \\
\text { variables }\end{array}$ & $\mathrm{B}$ & $\begin{array}{c}\text { Non-standard } \\
\text { Standard error }\end{array}$ & $\begin{array}{c}\text { Significance } \\
\text { level }\end{array}$ \\
\hline Constant term & 2.822 & 0.179 & 0.000 \\
Talents attraction & -0.103 & 0.084 & 0.221 \\
Talents selection & -0.039 & -.129 & 0.764 \\
Talents development & 0.108 & 0.107 & 0.317 \\
Talents sustainability & 0.099 & 0.111 & 0.375 \\
Talents appraisal & 0.232 & 0.106 & $0.032 *$ \\
\hline
\end{tabular}

Results relating to first hypothesis: which reported that "there is no a statistically significant impact at level $(\alpha=0,05)$ for the talents management in its dimensions (attraction, selection, development, sustainability and appraisal) on the provision of morning reports by resident doctors on patients at educational hospitals of the Jordanian MOH."

To verify this assumption, Person's correlation coefficients were calculated between the estimates of sample individuals on talents management variables and estimates on the variable of providing morning reports and academic duties, where the results were as shown in table 6 .

Table 6. Person's correlation coefficients between the estimates of sample individuals on talents management variables and estimates on the variable of providing morning reports and academic duties

\begin{tabular}{|c|c|c|}
\hline \multirow{2}{*}{ Talents management } & \multicolumn{2}{|c|}{ Variable of providing morning reports and academic duties } \\
\hline & Value of correlation coefficient & Statistical significance \\
\hline Variable of talents attraction & 0.42 & $0.000 *$ \\
\hline Variable of talents selection & 0.54 & $0.000 *$ \\
\hline Variable of talents development & 0.55 & $0.000 *$ \\
\hline Variable of talents sustainability & 0.62 & $0.000 *$ \\
\hline Variable of talents appraisal & 0.59 & $0.000 *$ \\
\hline
\end{tabular}


Table 6 shows that there is a statistically significant impact at level $(\alpha \leq 0.05)$ between he estimates of sample individuals on variables of talents management and their estimates on the variable of providing morning report and academic duties.

And, to know the size of talents management variable impact and estimates on the variable of providing morning reports and academic duties, multiple linear regression analysis was conducted, where the results were as shown in table 7 below:

Table 7. Results of implementing multiple regression equation to study talents management variable and estimates on the variable of providing morning reports and academic duties $(n=77)$

\begin{tabular}{lccc}
\hline \multicolumn{1}{c}{ Independent variables } & B & $\begin{array}{c}\text { Non-standard } \\
\text { Standard error }\end{array}$ & Significance level \\
\hline Constant term & 1.396 & 0.247 & 0.000 \\
Variable of Talents attraction & -0.063 & 0.116 & 0.587 \\
Variable of Talents selection & -0.013 & 0.179 & 0.943 \\
Variable of Talents development & 0.089 & 0.148 & 0.548 \\
Variable of Talents sustainability & 0.382 & 0.154 & $0.015^{*}$ \\
variable of Talents appraisal & 0.305 & 0.147 & $0.042^{*}$ \\
\hline
\end{tabular}

Table 7 shows the presence of a predictive capability for the impact of talents sustainability and talents appraisal variables, on the provision of morning reports and academic duties variable. That is ascribed to that the implementation of talents management and the presence of gifted resident doctors would positively reflect on the doctors performance especially the provision of morning reports, as the gifted resident doctors will perform whatever is required of them including paper and clerical works and that may be ascribed to the robust correlation between the variable of talents sustainability and appraisal and the provision of morning reports, as the educational hospitals, if they were incubators of medical talents and especially the resident doctors, so that will reflect on carrying out all paper and clerical works required from the resident doctors, yet, as for the variable of talents appraisal it may be ascribed to correlating part of the resident doctors' performance with what they provide of morning reports.

Results relating to second hypothesis: which stated that "there is no a statistically significant at the significance level $(\alpha=0,05)$ for talents management in its dimensions (attraction, selection, development, sustainability and appraisal) to carrying out morning rounds by resident doctors to patient at the educational hospitals of the Jordanian MOH".

To check this assumption, Person's correlation coefficients were calculated between the estimates of sample individuals on the variables of talents management and respective estimates on the variable to carrying out morning rounds to patients, where the results were as shown in table 8 .

Table 8. Person's correlation coefficients between the estimates of sample individuals on variables of talents management and estimates on the variable of carrying out morning rounds to patients

\begin{tabular}{lcc}
\hline \multicolumn{1}{c}{ Variables } & \multicolumn{2}{c}{ Variable of conducting morning rounds to patients } \\
& Value of correlation coefficient & Statistical significance \\
\hline Variable of talents attraction & 0.29 & $0.011^{*}$ \\
Variable of talents selection & 0.41 & $0.000^{*}$ \\
Variable of talents development & 0.42 & $0.000^{*}$ \\
Variable of talents sustainability & 0.41 & $0.000^{*}$ \\
Variable of talents appraisal & 0.49 & $0.000^{*}$ \\
\hline
\end{tabular}

Table 8 shows that there is a statistically significant impact at the significance level of $(\alpha \leq 0.05)$ between the estimates of sample individuals on the variables of talents management and respective estimates on the variable of morning rounds to patients. That may be ascribed to that when hospitals apply talents management that will reflect positively on carrying out morning rounds by resident doctors along with specialist and consultant doctors, the fact that will boost their medical skills and knowledge, and it's possible to hold resident doctors accountable in case of not carrying out such rounds, and to recognize the size of talent management variable impact and estimations on the 
variable of doing morning rounds to patients, multiple linear regression analysis was conducted, and the results were as shown in table 9 .

Table 9. Results of implementing the equation of multiple regression to study talents management variable and estimates on doing morning rounds to patients variable $(n=77)$

\begin{tabular}{lccc}
\hline Independent variables & B & $\begin{array}{c}\text { Non-standard } \\
\text { Standard error }\end{array}$ & Significance level \\
\hline Constant term & 2.261 & 0.257 & 0.000 \\
Talents attraction & -0.084 & 0.121 & 0.487 \\
Talents selection & 0.012 & 0.186 & 0.949 \\
Talents development & 0.121 & 0.154 & 0.435 \\
Talents sustainability & 0.080 & 0.160 & 0.620 \\
Talents appraisal & 0.349 & 0.153 & $0.026^{*}$ \\
\hline
\end{tabular}

Table 9 shows the presence of a predictive capability for the impact of talents appraisal on the variable of doing morning rounds to patients, and that may be ascribed to that specialist and consultant doctors, in charge of resident doctors, are an essential part of appraising the resident doctors through what the latter do, in morning rounds, along with them.

Results relating to third assumption: which stipulated that "there is no a statistically significant impact at the significance level $(\alpha=0,05)$ for talents management in its dimensions (attraction, selection, development, sustainability and appraisal) to carrying out diagnostic procedures at the educational hospitals of the Jordanian MOH".

To check this assumption, Person's correlation coefficients were calculated between the estimates of sample individuals on the variables of talents management and respective estimates on the area of following up diagnostic procedures and medical order for patients, where the results were as shown in table 10.

Table 10. Person's correlation coefficients between the estimates of sample individuals on the variables of talents management and estimates on the variable of following up diagnostic procedures and medical orders for patients

\begin{tabular}{lcc}
\multicolumn{1}{c}{ Variables } & \multicolumn{2}{c}{$\begin{array}{c}\text { Variable of following up diagnostic procedures and medical } \\
\text { orders for patients }\end{array}$} \\
& $\begin{array}{c}\text { Value of correlation coefficient } \\
\text { Statistical significance }\end{array}$ \\
\hline Variable of talents attraction & 0.45 & $0.000^{*}$ \\
Variable of talents selection & 0.52 & $0.000^{*}$ \\
Variable of talents development & 0.56 & $0.000^{*}$ \\
Variable of talents sustainability & 0.37 & $0.000^{*}$ \\
Variable of talents appraisal & 0.42 & $0.000^{*}$ \\
\hline
\end{tabular}

*with a statistical significance at $(\alpha \leq 0.05)$

Table 10 shows the presence of a statistically significant impact at the significance level of $(\alpha \leq 0.05)$ between the estimates of sample individuals on the variables of talents management and respective estimates on the variable of following up diagnostic procedures and medical orders for patients. And, that gets back to that the implementation of talents management at the educational hospitals entails doing all works required by resident doctors including following up the diagnostic procedures that are essential to resident doctor job. And, to recognize the size of talents management area impact and estimates on the variable of following up diagnostic procedures and medical orders for patients, multiple linear regression analysis was performed where the results found were as in table 11. 
Table 11. Results of implementing the equation of multiple regression to study talents management variable and estimates on the variable of following up diagnostic procedures and medical order for patients $(n=77)$

\begin{tabular}{lccc}
\hline \multicolumn{1}{c}{ Independent variables } & B & $\begin{array}{c}\text { Non-standard } \\
\text { Standard error }\end{array}$ & $\begin{array}{c}\text { Significance } \\
\text { level }\end{array}$ \\
\hline Constant term & 3.529 & 0.272 & 0.000 \\
Talents attraction & -0.142 & 0.127 & 0.269 \\
Talents selection & 0.019 & 0.196 & 0.923 \\
Talents development & 0.123 & 0.163 & 0.451 \\
Talents sustainability & -0.009 & 0.169 & 0.959 \\
Talents appraisal & 0.066 & 0.162 & 0.682 \\
\hline
\end{tabular}

* with a statistical significance at $(\alpha \leq 0.05)$

Table 11 shows that there is no predictive power to the impact of talents management on the variable of following up diagnostic procedures and medical orders for patients, and it can be said that the lacking of predictive power due to that all resident doctors carry out following up diagnostic procedures, and sometimes, a number of medical cadres like radiology and anesthesia technician do follow up the diagnostic procedures for patients.

Results relating to assumption four: which stipulated that "there is no a statistically significant impact at the significance level $(\alpha=0,05)$ for talents management in its dimensions (attraction, selection, development, sustainability and appraisal) on carrying out examination and admission of patients during night shifts at educational hospitals of the Jordanian MOH".

To check this assumption, Person's correlation coefficients were calculated between the estimates of sample individuals on the variables of talents management and respective estimates on the variable of examination and admission of patients during evening and night shifts, where the results were as shown in table 12 .

Table 12. Person's correlation coefficients between the estimates of sample individuals on the variables of talents management and estimates on the variable of examination and admission of patients during evening and night shits

\begin{tabular}{lcc}
\hline \multicolumn{1}{c}{ Variables } & \multicolumn{2}{c}{$\begin{array}{c}\text { Variable of following up diagnostic procedures and } \\
\text { medical orders for patients }\end{array}$} \\
& $\begin{array}{c}\text { Statistical significance } \\
\text { Value of correlation coefficient }\end{array}$ & $0.000^{*}$ \\
\hline Variable of talents attraction & 0.51 & $0.000^{*}$ \\
Variable of talents selection & 0.53 & $0.000^{*}$ \\
Variable of talents development & 0.48 & $0.000^{*}$ \\
Variable of talents sustainability & 0.38 & $0.000^{*}$ \\
Variable of talents appraisal & 0.61 & \\
\hline
\end{tabular}

Table 12 shows the presence of a statistically significant impact at the significance level of $(\alpha \leq 0.05)$ between the estimates of sample individuals on the variables of talents management and respective estimates on the variable of examining and admitting patients during evening and night shifts. It's noted that educational hospitals practice some of talents management that impact positively on carrying out the examination and admission of patients by resident doctors during evening and night shifts as they are deemed of the resident doctor's core function at the educational hospitals of the Jordanian MOH.

And, to know the size of talents management variable impact and estimates on the variable of examining and admitting patients during evening and night shifts, multiple linear regression analysis was conducted, where the results were as shown in table 13 below: 
Table 13. Results of implementing the equation of multiple regression to study talents management variables and estimates on the variable of examining and admitting patients during evening and night shifts $(n=77)$

\begin{tabular}{lccc}
\hline \multicolumn{1}{c}{ Independent variables } & B & $\begin{array}{c}\text { Non-standard } \\
\text { Standard error }\end{array}$ & Significance level \\
\hline Constant term & 3.555 & 0.202 & 0.000 \\
Talents attraction & -0.110 & 0.095 & 0.252 \\
Talents selection & -0.136 & 0.146 & 0.353 \\
Talents development & 0.100 & 0.121 & 0.411 \\
Talents sustainability & 0.001 & 0.126 & 0.993 \\
Talents appraisal & 0.254 & 0.120 & $0.038^{*}$ \\
\hline
\end{tabular}

Table 13 shows that there is a predictive power to the impact of talents management variables on the variable of examination and admission of patients during evening and night shifts. That may be ascribed to that the system of talents appraisal, as any other appraisal system, depends mainly on carrying out the works required from resident doctors especially when they are the only party responsible for the examination and admission of patients during evening and night shifts.

\section{Discussion of the Most Prominent Results of Study}

The study showed that the level of applying talents management at educational hospitals of the Jordanian MOH was moderate, and this result may be ascribed to ambiguity of talents management system among the administrators and workers at educational hospitals of the Jordan $\mathrm{MOH}$, and the size of practices performed by the educational hospitals and officials of the Jordan $\mathrm{MOH}$ to discover, procure and develop talents are not adequate, and this negatively reflects on achieving the goals sought and established for them, this result agrees with what was concluded by AL-JARRAH \& ABU DOLEH (2015) study, and that may be ascribed to that the organizations considered, in both studies, are government organizations, whereas the results disagreed with the results of AL-KASASBEH (2016) study, yet, as for the level of resident doctors' performance at educational hospitals of the Jordan MOH, which is moderate, it can be said that that that may be ascribed to the large number of patients inside the educational hospitals, which would lead to creation of pressures on resident doctors at such hospitals, and therefore, a delay in completing the works required from them, and to short number of resident doctors in some majors, which would also create pressure on the performance of resident doctor on which the work is focused, and also, this disagrees with the results of LAKE (2013) study and that may be ascribed to difference in medical system between Australia and Jordan; however, as for the presence of talents management impact in its dimensions on the resident doctors performance at educational hospitals of the Jordan $\mathrm{MOH}$, then, that may be ascribed to some practices of talents management followed by the educational hospitals, and that agrees with the KAUR (2013) study and as well as MUQRI \& YAHYAWI (2013) study.

\section{Recommendations}

1. Create departments responsible for gifted doctors at educational hospitals of the Jordan MOH.

2. Develop systems and mechanisms to attract, select and employ resident and gifted doctors at educational hospitals of the Jordan MOH.

3. Develop appraisal systems for the performance of gifted resident doctors, at the educational hospitals, marked by fairness and transparency.

4. Hospital administrations should keep up with modern management thinking in the field of talents management, and provide all aids and tools needed by the talents to complete and translate their capabilities.

5. Develop resident doctors at the educational hospitals, and tend to raise their performance level, as that would impact and reflect on the quality of service provided by such hospitals.

6. Conduct similar studies on private hospitals to measure the effect of talents management on resident doctors there.

\section{References}

Al-Aqili, O. (2015). Human Resources Management. Amman, ZAHRAN Publication Establishment.

Al-Jarrah, S., \& Abu Doleh, J. (2015). impact of implementing talents management on reinforcing organizational affiliation among faculty members at official Jordan Universities. Jordan Journal in Business Administration, 11(1), 283-215. 
Al-Kasasbeh, M. (2016). Impact of talents management and organizational learning in the sustainability of ZEIN Company. Jordan Journal in Business Administration, 12(1), 93-109.

Al-Saeed, M. (2013). Impact of talents management on merging workers via balancing between work and family as an intermediary variable, field study on AL-ZEQAQ University Hospital. Jordan Journal in Business Administration, 9(1), 22-40.

Armstong, M. (2009). A strategic Human Resource Management: a Guide to Action (4th ed.). Great Britain, Cambridge University Press, London.

Arnold, H., \& Feidman, D. (1983). Organizational Behavior. New York, McGraw- Hill Book Co.

Bartram, T., \& Casimir, G. (2007). The Relationship Between Leadership and Follower in Role Performance and Satisfaction with the Leader: the Mediating Effect of Empowerment and Trust in the Leader. Leadership \& Organization Development Journal, 28, 4-18.

Caravan, T., \& Carbery, R. (2012). Development, Definition, Scope Architecture. European Journal of Training \& Development, 36(1), 5-24. https://doi.org/10.1108/03090591211192601

Choudhary, R., Rangneker, S., \& Baura, M. (2014). Organizational Engagment, Climate Strength and Work Engagment. Journal of Procedia-Social and Behaviroal Science, 133(15), 291-303.

Colchin, S. (2014). Defining Talent Management Components. Advanced Computational Techniques in Electromagnetics, 14, 1-7.

David, D., Stephen, R., \& Susan, V. (2011). Human Resource Management (11th ed.). New York.

Echols, M. (2007). Winning the Turn Over War. Retrieved from www.talentmgt.com

Guthridge, M., Mcpherson, J., \& Wolf, W. (2008). Upgrading Talent. The Mickensy Quarterly, 1, 19-32.

Hamidi, N., Sabri, H., \& Safari, M. (2014). The Effect of Implementation of Talent Management on Job Satisfaction in Governmental Organization, Case Study, Ministry of Road and Urban. Journal of Novel Applied Science, 3, 100-113.

Jordan Government- MOH: job description of resident doctors.

Kaur, R. (2013). Empirical Study of Talent Management Program and its Impact on Employee Retirement and Performance in India Supermarket (big bazaar). Journal of Human Resource Management Research, 3(3), 61-70.

Lake, F., Celenza, A., \& Carr, S. (2013). Assessment of Junior Doctor Performance: Validation Study. BMC MED Journal, 13, 129-142. https://doi.org/10.1186/1472-6920-13-129

Marri, Z., \& Hayawi, N. (2014). Effect of talents management on the institution performance through organizational commitment, field study in the National Institutions for Juices and Food Preservatives. College of Administration and Economy Journal, 7(31), 17-41.

Michaels, E., Handled-Jones, H., \& Axerlod, B. (2001). The War for Talent. Boston, Harvard business school Press.

Oladapo, V. (2014). The Impact of Talent Management on Retention. Journal of Business Study Quarterly, 5(3), 19-36.

Piansoongern, O., \& Anuri, P. (2010). Talent Management: Quantitative and Qualitative Studies of H.R Practitioner in Thailand. The International Journal of Organizational Innovation, 3(1), 280-302.

Saleh, H., \& Al-Sudani, A. (2010). Talents management, conceptual and strategic perspectives for the repercussions and returns on knowledge business organizations, general administration institute journal, Sultanate of Oman, pp. 112-128.

Shuler, R., \& Peter, J. (1990). International Dimensions of Human Resources Management. New York, Wiley.

Tarique, I., \& Schuler, R. (2012). Framework and Review of Global Talent Management and Suggestion for Future Research. Journal of World Business, 45, 122-133.

Viaman, V., \& Vance, C. (2008). Smart Talent Management: Building Knowledge, Asset for Competitive Advantage. Edward Elgar Publishing L.T.D. 